\title{
Development of Learning Media Based on Arthropoda (Crustacea) Filum Diversity in Kampai Island of SD Negeri 050778 Langkat District, Sumatera Utara
}

\author{
Budianto ${ }^{1, a^{*}}$, Pandu Prabowo Warsodirejo $0^{1, b}$ \\ ${ }^{1}$ Faculty of Teachers Training and Education, North Sumatera Islamic University, Medan, 20217, Indonesia \\ a budianto@fkip.uisu.ac.id; b panduprabowo@fkip.uisu.ac.id \\ ${ }^{*}$ Corresponding Author \\ Whatsapp Number [ $1 a+6282277180617 ; 1 b+6283197194908]$
}

How to Cite : Budianto, B., Warsodirejo, P., P. (2019). Development of Learning Media Based on Arthropoda (Crustacea) Filum Diversity in Kampai Island of SD Negeri 050778 Langkat District, Sumatera Utaral. International Journal for Educational and Vocational Studies, 1 (5), 489-494

\section{ARTICLE HISTORY}

Received: 13 July 2019

Revised: 22 July 2019

Accepted: 24 August 2019

\section{KEYWORDS}

Learning Media;

Phylum Arthropods;

Crustaceans;

Research Development;

Abundance Index;

\begin{abstract}
This study aims to develop learning media that can be used by natural science teachers in SD Negeri 050778 by referring to RND-based media development methods (Research and Development) which will later use descriptive analysis methods and development methods. In making Blended Learning media where this media is in the form of learning videos using the Camtasia and Wondershare Quiz Creator application contains recorded video clips and questions about how to sample species, species diversity, and species collection techniques from Phylum Arthropods at SD Negeri 050778 Kampai Langkat Island, North Sumatra. The purpose of this research is descriptive analysis which is to obtain data on the diversity of the Artrhopoda Phylum from the Crustacean class which is very numerous and easily found around the coast of the island of Kampai. Crustacean diversity data obtained were analyzed using species abundance analysis method. Then the learning video development data will then be tested on students and science teachers as a test sample. From the field results found 8 dominant species of the Decapoda Order, including the Mangrove Crab (Scylla serrate), tiger shrimp (Panaeus monodon), Lobster Shrimp (Panulirus sp.), Ghost Crab (Ocypode kuhlii), Crab Uca Viola (Uca vocans), Uca Petarung Crab (Uca annulipes), Centipede Shrimp (Squilla mantis), Klomang (Bernhardus Pagurus). From the three stations where Crustacea species sampling locations were obtained a diversity index of $0.85 \%$ at Station 1 with Species dominance, namely Centipede Shrimp, then $1.76 \%$ at Station II with Species dominance, namely Klomang (Pagurus bernhardus), and $0,43 \%$ with species dominance, namely Shrimp Prawn (Panaeus monodoni). From the analysis calculations of 30 students the results of a large group trial for development data are: (a) a group of 30 students an average of $97.85 \%$ (very decent), (2) Science Teacher Test Data of $87 \%$ (feasible category)
\end{abstract}

This is an open access article under the CC-BY-SA license.

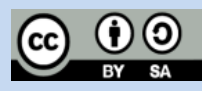

\section{INTRODUCTION}

North Sumatera Province is Located on the geographical coastline between $1-4$ degree $\mathrm{N}$ and 98 - 100 Degree East, in the north bordering Naggroe Aceh Darussalam (NAD) Province, while in the south is bordered by West Sumatera Province and Riau Province. The West Coast of North Sumatera faces the Indian Ocean Directly, while the East Coast faces the Strait of Malacca The total area of North Sumatra Province is $711,680 \mathrm{~km}^{2}(3.72 \%$ of the total area of the Republic of Indonesia). The East Coast of North Sumatra has a $545 \mathrm{~km}$ coastline. The east coast region of North Sumatra consists of 7 Regencies/Cities, namely: Langkat Regency, Medan City, Tanjung Balai City, Asahan Regency, Labuhan Batu Regency, Deli Serdang Regency and Serdang Bedagai Regency. Kampai Island is one of the largest islands owned by the Langkat Regency. North Sumatra Province. Kampai Island has a great potential to develop both in terms of education and natural resources.

Although classified as a small island, this island has quite a number of inhabitants who inhabit the island. The standard of living of the population is supported by livelihoods divided into 2 large groups namely the Farmers and Fishermen groups. Biologically, the Kampai Island Ecosystem is still in the good category and the topography of the island in general is in the form of an island with coral beaches and some sandy beaches with vegetation dominated by coconut plants, mangroves and coastal plants. With the structure of soil in the form of red soil and sandy soil is a component that makes the land of the island of Kampai pretty barren. Although $30 \%$ of the soil structure 
in the center of the island is peat. The condition of the beach is still quite good and classified as undamaged, making it along the coast of the island of Kampai has a wealth of natural resources rich animal species of invertebrate phylum. While 050778 Public Elementary School which is the only one on the island of Kampai has inadequate laboratory conditions both in terms of preserved samples and laboratory physical conditions. The condition shows the very opposite between the abundant natural wealth on the coast while the school is not empowered because it does not have a sample of preserved animals as a medium for learning science. In making instructional videos as a medium to be presented, research generally uses the Research and Depelopment (R\&D) method according to Borg and Gall (1996) consisting of 10 stages, namely (1) collecting initial data, (2) planning, (3) making Initial product and expert validation, (4) Initial trials, (5) Initial Product Improvements, (6) Field trials, (7) Operational Product Improvements, (8) Operational trials, (9) Repair of final Products, and ( 10) National Desemination. But even though certain processes of developing instructional media can be limited as needed based on field analysis. Research on the island of Kampai by utilizing the abundance of species diversity from Crustaceans has never been done. Research on diversity can be used as material objects as learning media, especially learning videos. Documentary videos that describe a variety of species are ideal learning media for elementary school children, especially science subjects. From this study utilizing the natural environment which is an abundant source of natural science, of course, can produce interesting learning videos for these elementary school students. Crustaceans in Latin, crusta means shell. Crustaceans are also called shellfish. It is well known that approximately 26,000 types of crustaceans are the most common shrimp and crab. Crustacean habitat is mostly in fresh water and seawater, only a few that live on land. Crustaceans are segmented (segmented) and consist of cephalothorax (head and chest together) and abdomen (stomach). The anterior (front end) of the body is larger and wider, while the posterior (back end) is narrow. On the head there are several mouth tools, namely: 2 pairs of antennas, 1 pair of mandibles, to bite prey, 1 pair of maxilla, 1 pair of maxilliped. Maxilliped and maxillary function to filter food and deliver food to the mouth. Motion apparatus in the form of legs (one pair of each segment on the abdomen) and serves to swim, crawl or stick to the bottom of the water.

\section{METHODS}

\subsection{Research Location, Station Description, and Research Time}

The study took video shooting locations on the east coast of Kampai Island which is divided into 3 stations. Station 1 is the northeastern region, Station 2 is the eastern part and Station 3 is the southeast part of Kampai Island. And the location of the video trial was conducted at 050778 Public Elementary School in Kampai Island. The study was conducted from March to July 2019.

\subsection{Operational Defenition}

This research has two operational definitions, namely:

a. Species diversity from the Arthropod phylum taken only from the Crustacean class. Excludes other classes or orders in the Arthropod Phylum. Species obtained in the field where the data are collected are then identified in the laboratory based on their taxonomy and classification.

b. The Learning Media in this study is meant in the form of a simple but interesting learning video that is intended for elementary school children 050778 in the science material, especially Biology of Living Creatures Diversity.

\subsection{Types of Research}

This type of research is development research based on the $\mathrm{RnD}$ (Development Research) database. However, the data obtained in the field are also presented in the form of an abundance index which is calculated and obtained using the ecological method of diversity index and species abundance using station coverage. The Development Model used is the Dick and Carey and Borg and Gall models with the following stages:

a. The identification phase includes: (a) identification of the objectives, characteristics of students' materials, facilities, and equipment and (b) identification of the curriculum, to determine teaching material.

b. Design and development stage. This phase of the activity is designing and developing programs in the form of design documents according to the steps adapted from the Dick \& Carey model, including the preparation of flow charts, script writing, and storyboards. The steps in this stage are: (a). formulation of competency standards, (b). analysis of competency standards, (c). identification of initial abilities and characteristics of students, (d). formulating learning competencies, (e). choose learning strategies and learning experiences, (f). translation of basic competencies into indicators, (g). development of test items based on benchmark standards

c. Production stage. Activities in this stage are making all media objects (assembly), for example making images (image), clip art, animation and video.

d. Evaluation stage. The evaluation phase is carried out with the following steps: a. Vaidation and trials include: (a) Validation of subject matter experts and instructional media experts, (b) individual trials, (c) small group trials, and (d) field trials. b. The revision stage, there are two kinds, namely: (a) changes to the learning material in the presentation of learning media. (b) the results of the revision based on input from the trial will be obtained by the final product.

\subsection{Product Testing}

The subjects of the research product trial were grade $\mathrm{V}$ and 
VI students of SD Negeri 050778 Kampai Island and Lessons who taught Biology (Natural Sciences). The total number of subjects was 30 students as a large group, and elementary school natural science teachers as many as 4 natural science teachers.

\subsection{Data Collection Techniques}

a. Data on species diversity of phylum arthropods (crustaceans)

Done using a guide to the station abundance index analysis method. The species that are found are then collected and then placed into separate containers for each station. Then for the total species found, the largest abundance index was calculated for each station.

\section{b. Media Development Data}

Data obtained using a simple questionnaire consisting of simple elements in the process of taking a qualitative descriptive description. Data from students in the form of aspects that are more inclined to aspects of the media, namely ease of understanding media, logic of thinking, interaction with users, use of language, use of images, colors, animation, background or backsound, and slide shows. While data from the teacher in the form of aspects that are more inclined to aspects of the material where the teacher is more reviewing the terms of the material to be consumed by students as a learning medium, namely conformity to the syllabus of learning, clarity of topics, material coverage, image relevance, illustration of animal images, attraction of animation, and ease of understanding the material.

\subsection{Data Analysis Techniques}

Video media analysis data is calculated quantitatively then calculates the average score of each sub-aspect by the formula: $\mathrm{X}=\Sigma \mathrm{X} / \mathrm{n}$ where $\mathrm{X}$ is the average score, $\Sigma \mathrm{X}$ is the number of scores, and $\mathrm{n}$ is the number of reviewers. Then change the average score into a qualitative value with the category of eligibility for each aspect following the feasibility table obtained from the Mean Ideal and the calculation is accumulated into the formula for the percentage of eligibility from each aspect of assessment: Percentage of Eligibility (\%) = (Observation score / Expected score) x $100 \%$. The collected data were analyzed with quantitative analysis techniques which were expressed in the distribution of scores and percentages of the specified rating scale categories. After serving as a percentage, the next step is to describe and draw conclusions about each indicator. The suitability of aspects in the development of instructional media uses a scale table for the feasibility percentage of Arikunto (1996: 24), namely: 76-100\% (WORTH), 56-75\% (WORTH ENOUGH), 40-55\% (WORTH LESS), 0-39\% (NOT FEASIBLE). While CRUSTACEA Diversity Data obtained is calculated using the D index (Density), Specific Wealth (R), and the Diversity $\mathrm{H}$ index (diversity).

\section{RESULTS AND DISCUSSION}

Here are the data from the field observations:

a. Data on Crustacean species

Table 1. List of Crustacean species identified at each station in the Study site :

\begin{tabular}{cllcc}
\hline No. & Species name & Station I & Station II & Station III \\
\hline 1 & Scylla serrate (kepiting bakau) & 1 & 0 & 3 \\
\hline 2 & Panaeus monodon (Udang windu) & 10 & 2 & 3 \\
\hline 3 & Panulirus sp (Udang Lobster) & 5 & 1 & 7 \\
\hline 4 & Ocypode kuhlii (Kepiting Hantu) & 2 & 4 & 6 \\
\hline 5 & Uca vocans (Kepiting biola) & 2 & 4 & 5 \\
\hline 6 & Uca annulipes (Kepiting uca Petarung) & 3 & 13 & 5 \\
\hline 7 & Squilla mantis (Udang Lipan) & 15 & 17 & 7 \\
\hline 8 & Pagurus bernhardus (Klomang) & 56 & 48 \\
\hline
\end{tabular}

Table 2. Amount of Species at Station 1 with Index Calculate

\begin{tabular}{|c|c|c|c|c|c|c|c|}
\hline No & Class & Species & Amount & $\mathrm{Pi}$ & Ln.pi & $\mathrm{Pi}$ (Ln.pi) & $S$ \\
\hline 1 & Cruscacean & Panaeus monodon & 10 & 5.6 & 1.66 & 9.2998621 & \multirow{4}{*}{0,85} \\
\hline 2 & Cruscacean & Squilla mantis & 18 & 10.08 & 2.99 & 30.131553 & \\
\hline \multirow[t]{2}{*}{3} & Cruscacean & Pagurus bernhardus & 15 & 8.4 & 2.49 & 20.92469 & \\
\hline & & TOTAL & 43 & 24.08 & 7.14 & 60.356105 & \\
\hline
\end{tabular}


Table 3. Amount of Species at Station 2 with Index Calculate

\begin{tabular}{|c|c|c|c|c|c|c|c|}
\hline No & Class & Species & amount & $\mathrm{Pi}$ & Ln.pi & Pi (Ln.pi) & $S$ \\
\hline 1 & Cruscacean & Squilla mantis & 13 & 7.28 & 1.51 & 10.965186 & \\
\hline \multirow[t]{2}{*}{2} & Cruscacean & Pagurus bernhardus & 17 & 9.52 & 1.97 & 18.751117 & 1,76 \\
\hline & & TOTAL & 30 & 16.8 & 3.48 & 29.716303 & \\
\hline
\end{tabular}

Table 4. Amount of Species at Station 3 with Index calculate

\begin{tabular}{|c|c|c|c|c|c|c|c|}
\hline No. & Class & Species & Amount & $\mathrm{Pi}$ & Ln.pi & Pi (Ln.pi) & $S$ \\
\hline 1 & Ocypodidae & Panaeus monodon & 8 & 4.48 & 0.65 & 2.9067476 & \multirow{4}{*}{0,43} \\
\hline 2 & Ocypodidae & Pagurus bernhardus & 7 & 3.92 & 0.57 & 2.2254786 & \\
\hline \multirow[t]{2}{*}{3} & Ocypodidae & Uca vocans & 6 & 3.36 & 0.49 & 1.6350455 & \\
\hline & & TOTAL & 21 & 11.76 & 1.70 & 6.7672717 & \\
\hline
\end{tabular}

Table 5. Student Assessment Calculation Result Data from\% eligibility

\begin{tabular}{llccc}
\hline \multirow{2}{*}{ No. } & Aspect & \multicolumn{2}{c}{ Score } & \% \\
\cline { 3 - 5 } & & \multicolumn{2}{c}{ Expectation } & obervation \\
\hline 1 & Effects of Learning Strategies & 360 & 354 & $98,3 \%$ \\
\hline 2 & Communication & 360 & 358 & $99,4 \%$ \\
\hline 3 & Technical design & 480 & 464 & $96,6 \%$ \\
\hline & & Average & $97,85 \%$
\end{tabular}

\section{Station 1}

Based on the results of field observations obtained the highest number of species, namely Shrimp Centipede (Squilla mantisi) with the number of species is 18 tails. From the calculation of diversity index of $0.85 \%$ with the most dominant numbers are the Centipede Shrimp, Klomang and Windu Shrimp. In addition, the number of other species was obtained with the total number of species obtained at station 1 was 56 species.

\section{Station 2}

From the results of field observations, the highest number of species is Klomang (Pagurus bernhardus) with 17 species. From the calculation of diversity index of $1.76 \%$, the most dominant numbers are Klomang and Centipede shrimp. In addition, the number of other species was obtained with the total number of species obtained at station 2 was 48 species.

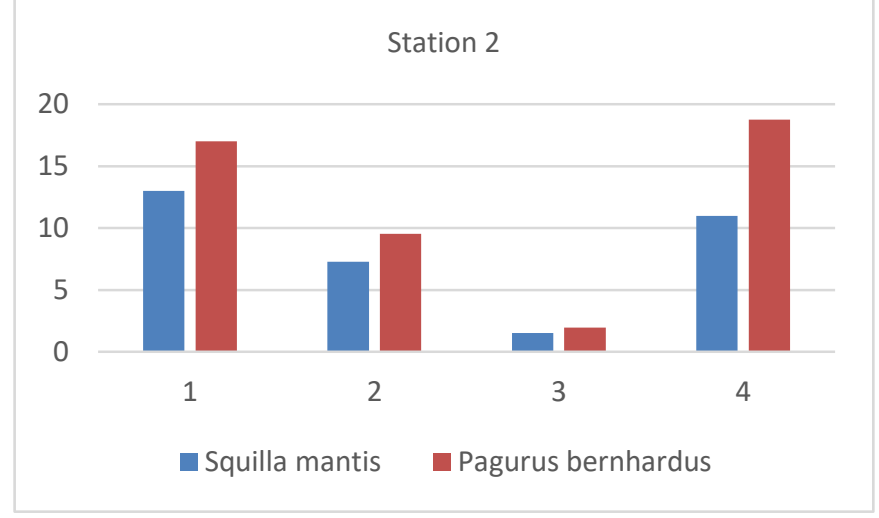

Figure 1. Draw bar graphic at station 1

\section{Station 3}

From the results of field observations obtained the highest number of species, namely tiger shrimp (Panaeus monodon) with the number of species is 8 tails. From the calculation of diversity index of $0.43 \%$, the most dominant numbers were tiger shrimp and violin crab. In addition, the number of other species was obtained with the total number of species obtained at station 3 was 41 species. 
Station 3

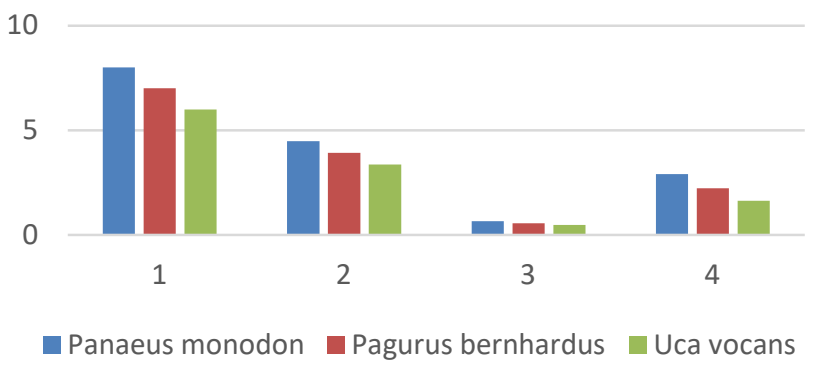

Figure 2. Draw bar graphic at station 3

After the shooting results in accordance with the storyboard/script of the learning video development are finished, the researchers then take a picture (shooting to the study site) and collect all the shooting material that has been collected and will then be adjusted using the Xilisoft Video Converter Ultimate 6 video editing application software program., into the wmv format. (Windows Media Video) and $\mathrm{mp} 4$ format. Then proceed to the editing process by inserting various images, sound effects, instrument music, and animation. Then it is produced entering the final stage by using video editing software using Camtasia Studio which functions to fully edit the entire video creation process. For making assessment (learning items), researchers used the Wondershare Quiz Creator software. After all is done then the prototype video will be packaged into a CD-RW through the burning process and autoplay. Broadly speaking, the learning video product development results contain: a) Introduction containing learning objectives, b) Material 1 Diversity of Crustaceans, in the form of a wmv video format. or mp4., c) Assessment in flash.

Test Results from a questionnaire of 30 students (Large group test). In general, aspects of the assessment tested were (1) Effects of learning strategies, (2) Communication, and (3) Technical Design. With the following results:

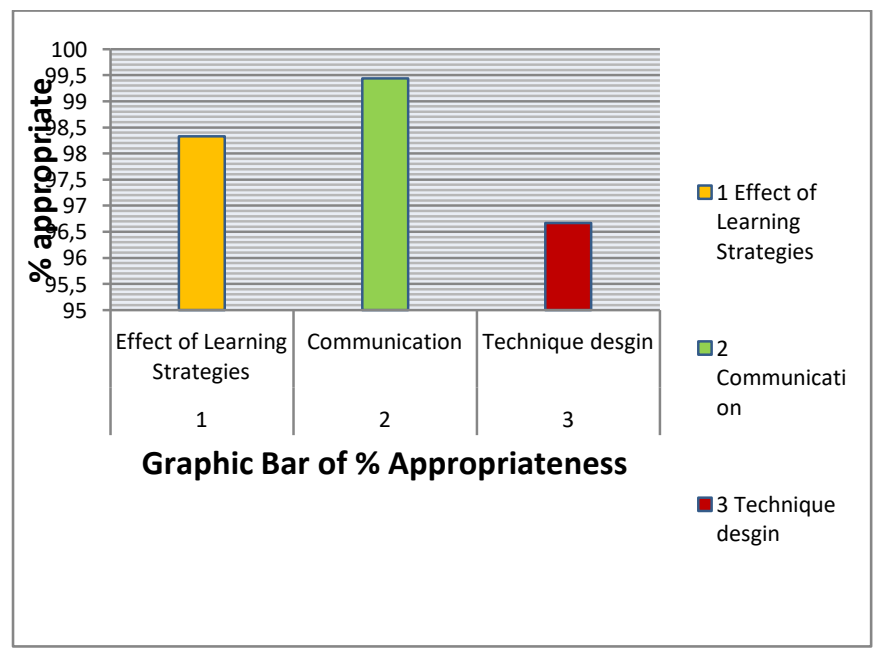

Figure 3. Draw bar graphic point of \% Appropriateness

\section{CONCLUSION}

This research can be further developed to see the enormous potential of Kampai Island as a learning resource that can be utilized by natural science teachers as a natural laboratory. From the field results found 8 dominant species of the Decapoda Order, including the Mangrove Crab (Scylla serrata), Tiger Shrimp (Panaeus monodon), Lobster Shrimp (Panulirus sp.), Ghost Crab (Ocypode kuhlii), Crab Uca Biola (Uca vocans), Uca Petarung Crab (Uca annulipes), Centipede Shrimp (Squilla mantis), Klomang (Bernhardus Pagurus). From the three stations where Crustacea species sampling locations were obtained a diversity index of $0.85 \%$ at Station 1 with Species dominance, namely Centipede Shrimp, then $1.76 \%$ at Station II with Species dominance, namely Klomang (Pagurus bernhardus), and 0,43\% with species dominance, namely Shrimp Prawn (Panaeus monodoni). From these data it can be concluded that the natural condition of the seaside ecology on Kampai Island is still relatively good and can still be used as a source of making or developing science learning media. While the media developed can take various forms. For further researchers, they can carry out further research and develop better and more attractive media in order to improve the pedagogical abilities of teachers as educators. Utilizing the potential of the natural surroundings is the teacher's Pedagogical ability that can support the improvisation of students' Psychomotor and Affective domains.

\section{REFERENCES}

Adel, M. (2001). Bacterial Decomposition of Avicennia marina Leaf Litter. Journal of Biological Science. 8: 717.719 .

Arif Sadiman., dkk. (2003). Media Pendidikan (Pengertian Pengembangan dan Pemafaatannya). Jakarta: CV Rajawali.

Azhar Arsyad. (2006). Media Pembelajaran. Jakarta: PT Raja Grafindo Persada.

Bengen, D. G. (2001). Sinopsis Ekosistem dan Sumberdaya Alam Pesisir dan Laut. Pusat Kajian Sumber Daya Pesisir dan Lautan. IPB. Bogor

Chia OKS, Ng PKL. (2006). The Freshwater Crab of Sulawesi, with Description of Two New Genera and Four New Species (Crustacea: Decapoda: Brachyura: Parathelphusidae). The Raffles Bulletin of Zoology, vol 54(2):381-428

Darsono, M, dkk. (2000). Belajar dan Pembelajaran. Semarang: IKIP Semarang Press

Departemen Kehutanan. (1997). Strategi Nasional Pengelolaan Kawasan Mangrove di Indonesia. Departemen Kehutanan. Jakarta.

Dimyati dan Mujiono. (1999). Belajar dan Pembelajaran. Jakarta: Rineka Cipta

Djamarah, S B. (2000). Psikologi Belajar. Banjarmasin : Reineka Cipta 
Djamali, A. R. (2004). Persepsi Masyarakat Desa Pantai Terhadap Kelestarian Hutan Mangrove. http://www.rudyct.com. [ 20 Oktober 2012 ].

Fachrul, M.F. (2007). Metode Sampling Bioekologi. Jakarta: PT Bumi Aksara.

Hanafiah, K.A., Napoleon, A. \& N. Ghofar. (2005). Biologi Tanah: Ekologi \& Makrobiologi Tanah. Jakarta: PT Raja Grafindo Persada.

Hoove, W.V. (1996). Ensiklopedi Indonesia Seri Fauna: Burung.Jakarta: PT. Ichtiar Baru Van Hoove

Kanna I. 2000. Budidaya Kepiting Bakau: Pembenihan dan Pembesaran. Yogyakarta: Penerbit Kanisius.

Krebs, C.J. (1989). Ecological Methodology. New York: Harper \& Row Publishers

Lewis, T. \& R. Taylor. (1976). Introduction to experimental ecology. London: Academic Press.

Ludwig, J.A \& J.F. Reynolds. (1988). Statistical Ecology: A Primer on Methods and Computing. New York: John Wiley \& Sons.

Magurran, A.E. (1988). Ecological Diversity and Its Measurement. London: Chapman and Hall.

Martin JW, Crandall KA, Felder DL. (2009). Decapod Crustacean Phylogenetics. USA: Taylor \& Francis Group. p 502

Gandjar, I. Wellyzar, S, dan Ariyanti, O. (2006). Ekologi Dasar dan Terapan. Yayasan Obor Indonesia. Jakarta

Nana Sudjana \& Ahmad Rivai. (2002). Media Pengajaran. Bandung: CV Sinar Baru.

Nana Sudjana. (1991). Teori-teori Belajar Untuk Pengajaran. Jakarta: Lembaga Penerbit Fakultas Ekonomi Universitas Indonesia.

Nasution. (1999). Teknologi Pendidikan. Jakarta: PT Bumi Aksara

Ng PKL. (1998). Crabs. In: FAO Species Identification Guide for Fishery Purposes. The Living Marine Resources of the Western Central Pacific. Vol. 2

Cephalopods, Crustaceans, Holothurians, and Sharks. (Carpenter KE \& Niems VH, eds.). Rome: FAO. pp 1045-1155

Poore GCB. (2004). Marine Decapod Crustacea of Southern Australia: A Guide to Identification. Australia: CSIRO Publishing. pp 22, 496.

Puspitasari N. (2013). Studi Kepadatan Komunitas Kepiting (Brachyura) Pada Ekosistem Mangrove di Kelurahan Wonorejo, Kecamatan. Rungkut, Surabaya Timur, Jawa Timur. [Laporan PKL]. Malang: Program Studi Kelautan Jurusan Pemanfaatan Sumber Daya Perikanan dan Kelautan Fakultas Perikanan dan Ilmu Kelautan Universitas Brawijaya

Riyadi, A.S. (2011). Pengembangan Media Pembelajaran Berbasis Komputer Untuk Mata DIKLAT Mengoperasikan Mesin CNC Dasar di SMK Negeri 2 Depok Sleman Yogyakarta. Prodi Pendidikan Teknik, Fakultas Teknik, UNY, Yogyakarta.
Sadiman, Arief. (1990). Media pendidikan, pengertian pengembangan dan pemanfaatan. Jakarta: Rajawali

Subagyo, P. J. (1997). Metode Penelitian dalam Teori dan Praktek. Rineka Cipta. Jakarta.

Suharsimi Arikunto. (1996). Prosedur Penelitian Suatu Pendekatan Praktek. Jakarta: PT. Rineka Cipta.

Sutopo, H. (2009). Pengembangan Model Pembelajaran Pembuatan Aplikasi Multimedia Khususnya Puzzle Game Pada Mata Kuliah Multimedia. Program Studi Teknologi Pendidikan, Program Pasca Sarjana, UNJ. Jakarta.

Widodo, A. (2005). Analisis Pembelajaan Biologi dengan Menggunakan Video. Paper disajikan dalam Seminar Nasional Pendidikan IPA III Himpunan Sarjana dan Pemerhati Pendidikan IPA Indonesia, 22-23 Juli 2005, Bandung. 